\title{
PLANT-PLANT INTERACTIONS IN PEA-CEREAL MIXTURES UNDER HEAT STRESS CONDITIONS OF SECOND CROP SEASON
}

\author{
Onur ILERI ${ }^{I}$, Sule ERKOVAN ${ }^{1}$, Halil Ibrahim ERKOVAN ${ }^{1, *}$, Ali KOC ${ }^{l}$ \\ ${ }^{1}$ Eskisehir Osmangazi University, Faculty of Agriculture, Department of Field Crops, Eskisehir, \\ TURKEY \\ *Corresponding author: erkovan@ogu.edu.tr
}

Received: 09.05.2021

\begin{abstract}
Plant-plant interactions could shift from facilitation to competition or vice versa depending on stress conditions. Many researchers are investigating these interactions among the plant species but knowledge about the effect of these interactions on the establishment and growth is limited. Therefore, the effect of plant-plant interactions on forage yield and quality were investigated in pea-cereal mixtures under Central Anatolia conditions during the 2018 and 2019 years. Forage pea were sown using different densities $(80,100,120$ plants $\mathbf{m}^{-2}$ ) and as binary mixtures with $\mathbf{5 0 - 7 5} \%$ reduced seeding ratio of oat, silage maize, and Sudangrass as a mixture. The highest dry matter yield was $7224.7 \mathrm{~kg} \mathrm{ha}^{-1}$ and, obtained from $50 \%$ reduced silage maize +100 plants $\mathrm{m}^{-2}$ forage pea mixture. All mixtures increased dry matter yield but decreased the crude protein content concerning forage pea monoculture. Sudangrass mixtures negatively affect the crude protein content in the mixture and decreased it down to $\mathbf{1 4 . 5 8} \%$ but it was, nevertheless, considerably high. Forage NDF and ADF contents were generally higher in Sudangrass mixtures. Above-and below-ground relative neighbor effects (ARNE and BRNE respectively) were facilitative under stressful climate conditions of 2018 but they shifted into competition in 2019. The cereals used in the mixtures caused a competitive effect on forage pea in terms of BRNE. The results indicated that plant-plant interactions could significantly affect the forage yield, quality, and competition. Forage pea $\left(100\right.$ plants $\left.\mathrm{m}^{-2}\right)$ could be cultivated as a second crop when sown as a binary mixture using $50 \%$ reduced silage maize $\left(5000\right.$ plants $\left.\mathbf{~ m}^{-2}\right)$.
\end{abstract}

Keywords: Forage pea, mixture, forage quality, plant-plant interaction, plant density

\section{INTRODUCTION}

Forage pea (Pisum sativum ssp. arvense) is a coolseason forage legume that has a high percentage of crude protein (Kocer and Albayrak, 2012), lysine as a restrictive amino acid (Mihailovic et al., 2007), digestible dry matter content and easy-cultivating characteristics make the plant a valuable forage crop. It is generally cultivated as a winter crop and could produce nearly 10 tons ha $\mathrm{h}^{-1}$ highquality forage and more than 4.5 tons $\mathrm{ha}^{-1}$ seed under optimum conditions (Uzun et al., 2005; Lithourgidis et al., 2011). The plant has great potential as the second crop especially for forage production but high summer temperatures cause severe abiotic stress conditions (Liu et al., 2019) because of the cool season characteristics of the plant. Although the pea is widely cultivated in Mediterranean environments where temperate climate conditions prevail, many researchers are indicating the sensitivity of the plant to heat stress (Jiang et al., 2015; Liu et al., 2019). Moreover, future projections of global climate researches indicated that temperatures would be on an increasing trend globally (Rogelj et al., 2012) especially warming in the winter period will rise in more provinces (Bhattacharya, 2019). The predictions are indicating that the increment will be more crucial as $1.4-$ $5.8{ }^{\circ} \mathrm{C}$ especially in the Mediterranean region including Turkey also (Planton et al., 2012). This increment in temperature could cause a risk for forage pea cultivation also in main crop conditions. Therefore, researchers should be focused on these possible risks at the cultivation of forage pea, a high-quality forage resource.

Plant density might be a factor to alleviate the heat stress by causing a microclimate area (Tafesse et al., 2019). Increasing plant density could also prevent the forage pea from lodging, an undesired event that causes yield and quality losses at a high rate (Smitchger and Weeden, 2019). However, density could be arranged by considering the competition responses of the plant because increasing plant density could also increase competition for the resources such as area, light, nutrient, $\mathrm{CO}_{2}$, etc. (Weigelt and Jolliffe, 2003; Zhai et al., 2018). Therefore, intercropping or sowing in mixtures are widely used in forage pea cultivation against lodging and these applications provide an effective usage of the fields 
(Kontturi et al., 2011; Podgorska-Lesiak and Sobkowicz, 2013).

Species should be chosen carefully for mixtures because plant-plant interactions in mixtures (relative neighbor effect) could shift easily from facilitation to competition or vice versa depending on the stress conditions (Koc et al., 2013; Grant et al., 2014) Facilitative effects were more evident in dry and hot conditions and it decreases the effect of these abiotic stresses (Brooker et al., 2008; He et al., 2013). Therefore, forage pea might be cultivated with warm-season crops in a mixture to utilize its high-quality forage by producing in the warm second crop conditions. Tall cereals as maize, sorghum, Sudan grass could provide a microclimate area for forage pea due to their shadow and this effect could be an opportunity to cultivate forage pea in a mixture under warm second crop conditions by alleviating the heat stress. Tall cereals cause a facilitative effect on forage pea under high-temperature conditions but under favorable conditions, especially sorghum and Sudan grass might inhibit the growth of forage pea and cause economic yield losses due to allelopathic effect (Cook et al., 2010).

This research was designed to determine the proper forage pea density and crop in the mixture for the forage pea cultivation under warm second crop conditions in Central Anatolia. Therefore, yield, forage quality, and competitive relations of the forage pea and some cereal mixtures were investigated in the study. Hypothesis were; a) Increasing plant density of forage pea might have positive effects on forage yield, quality, and relative neighbor effect b) Warm-season cereal mixtures may alleviate the heat stress on forage pea and therefore, highquality forage could be produced due to positive relative neighbor effects.

\section{MATERIALS AND METHODS}

The study was conducted on the experimental station of Eskisehir Osmangazi University, Faculty of Agriculture during 2018 and 2019. The experimental station is located within the Eskisehir Plain, has an altitude of 800 meters above sea level, and semi-arid terrestrial climate conditions prevail where precipitation mostly falls in winter and spring and summer months are hot and dry. In 2018, the area received higher precipitation; the main temperature and humidity were also higher than in 2019 (Table 1). The temperature in the experimental months of 2018 was higher about $3.6^{\circ} \mathrm{C}$ than in 2019 and severe drought was observed in the August of 2019 (Table 1).

Table 1. Climate data of the experimental area

\begin{tabular}{cccccccccc}
\hline Months & \multicolumn{3}{c}{ Precipitation $(\mathbf{m m})$} & \multicolumn{3}{c}{ Temperature $\left({ }^{\mathbf{0}} \mathbf{C}\right)$} & \multicolumn{3}{c}{ Humidity $(\boldsymbol{\%})$} \\
\hline & $\mathbf{2 0 1 8}$ & $\mathbf{2 0 1 9}$ & LTA & $\mathbf{2 0 1 8}$ & $\mathbf{2 0 1 9}$ & LTA & $\mathbf{2 0 1 8}$ & $\mathbf{2 0 1 9}$ & LTA \\
\hline January & 31.5 & 60.2 & 38.7 & 2.2 & 4.3 & 0.3 & 95.5 & 91.0 & 98.2 \\
February & 40.5 & 50.1 & 32.5 & 6.6 & 3.4 & 4.7 & 90.7 & 79.6 & 92.6 \\
March & 74.8 & 13.4 & 33.4 & 10.1 & 6.3 & 9.3 & 81.5 & 64.5 & 81.6 \\
April & 16.5 & 26.7 & 35.0 & 15.4 & 9.5 & 13.1 & 60.7 & 69.3 & 67.8 \\
May & 84.8 & 42.2 & 44.8 & 17.6 & 16.5 & 16.5 & 83.0 & 65.1 & 86.1 \\
June & $\mathbf{7 2 . 5}$ & $\mathbf{4 5 . 7}$ & $\mathbf{3 0 . 6}$ & $\mathbf{2 0 . 6}$ & $\mathbf{2 0 . 9}$ & $\mathbf{2 0 . 4}$ & $\mathbf{8 0 . 7}$ & $\mathbf{6 7 . 9}$ & $\mathbf{8 3 . 3}$ \\
July & $\mathbf{3 8 . 3}$ & $\mathbf{3 3 . 5}$ & $\mathbf{1 4 . 0}$ & $\mathbf{2 3 . 0}$ & $\mathbf{2 1 . 3}$ & $\mathbf{2 3 . 3}$ & $\mathbf{7 1 . 4}$ & $\mathbf{6 2 . 3}$ & $\mathbf{7 5 . 8}$ \\
August & $\mathbf{2 5 . 0}$ & $\mathbf{2 . 4}$ & $\mathbf{7 . 8}$ & $\mathbf{2 3 . 5}$ & $\mathbf{2 2 . 3}$ & $\mathbf{2 2 . 9}$ & $\mathbf{6 2 . 2}$ & $\mathbf{6 1 . 0}$ & $\mathbf{7 4 . 1}$ \\
September & $\mathbf{4 . 3}$ & $\mathbf{5 . 0}$ & $\mathbf{1 4 . 4}$ & $\mathbf{1 9 . 1}$ & $\mathbf{1 8 . 1}$ & $\mathbf{2 0 . 0}$ & $\mathbf{6 2 . 9}$ & $\mathbf{6 2 . 1}$ & $\mathbf{6 8 . 1}$ \\
October & 41.0 & 18.3 & 27.0 & 14 & 14.2 & 12.9 & 75.5 & 70.1 & 79.6 \\
November & 29.6 & 33.9 & 29.2 & 8.4 & 7.9 & 7.5 & 79.2 & 76.2 & 80.3 \\
December & 63.6 & 74.1 & 45.1 & 2.7 & 2.9 & 3.6 & 96.0 & 89.9 & 93.6 \\
\hline Tot./Ave. & 522.4 & 405.5 & 352.4 & 13.6 & 12.3 & 12.8 & 78.3 & 71.6 & 81.8 \\
\hline
\end{tabular}

LTA: Average climate data between 1929-2019

Bold lines: Growing season for the experiment

The soil characteristics of the experimental area were determined as clay-loam in texture, slightly alkaline, lime and organic matter contents were $14.6 \%$ and $1.62 \%$ (poor) respectively. Soil salinity level was quite low $(0.07$ $\%$ ) and $\mathrm{P}_{2} \mathrm{O}_{5}$ and $\mathrm{K}_{2} \mathrm{O}$ contents were 61.6 and $1688 \mathrm{~kg} \mathrm{ha}^{-1}$ respectively.

Forage pea (cv. Tore), maize (cv. Kilowatt), Sudangrass (cv. Gozde-80), and oat (cv. Cehecota) were used as plant materials and mixed in different ratios. The experiment was arranged in a completely randomized block design with a split-plot and using 3 replications. The main plots were plant densities of forage pea and the subplots were mixtures. Forage pea was sown at the rates of 80,100 , and 120 plants $\mathrm{m}^{-2}$ and as control (sole-sown), and in mixtures with maize, oat and Sudangrass by reducing the seeding rates as 50 and $75 \%$ considering the suggestions as 100000 plants ha $^{-1}$ for maize (Turgut et al., 2005), $180 \mathrm{~kg} \mathrm{ha}^{-1}$ for oat (Basaran et al., 2018) and $20 \mathrm{~kg}$ $\mathrm{ha}^{-1}$ for Sudangrass (Acikgoz, 2001).

Plants were cultivated as the second crop after wheat harvest and sown on 12 and 22 June in 2018 and 2019 years respectively depending on the wheat harvest in the region. Each plot consisted of $5 \mathrm{~m}$ of 5 lines in $30 \mathrm{~cm}$ row spacing $\left(7.5 \mathrm{~m}^{2}\right)$. Fertilizing was carried out using diammonium phosphate (DAP) as to be $30 \mathrm{~kg} \mathrm{ha}^{-1}$ nitrogen and $70 \mathrm{~kg} \mathrm{ha}^{-1} \mathrm{P}_{2} \mathrm{O}_{5}$ and irrigation was applied 4 times in 2018 and 5 times in 2019 using sprinkler and considering the requirement of the plants. 
The harvest stage was determined considering the seed traces in the lowest pods of forage pea as suggested by Onal-Asci et al. (2015) and all plants were harvested together with the forage pea. The harvest date was 15 and 4 September in 2018 and 2019 respectively. Mid three rows of all plots were harvested after taking out the $0.5 \mathrm{~m}$ from beginning and end of each row and oven-dried at 60 ${ }^{\circ} \mathrm{C}$ until reached to constant weight to determine the dry matter yield. Forage quality characteristics were determined from the samples used for dry matter yield estimations. Dry samples were grounded to pass through a $2 \mathrm{~mm}$ sieve, and crude protein (CP) content was determined using the Kjeldahl method. Neutral detergent fiber (NDF) and acid detergent fiber (ADF) contents were determined due to the detergent method suggested by Van Soest et al. (1991). In every plot, roots were excavated from a randomly selected $1 \mathrm{~m}^{2}$ area, washed, and ovendried at $70^{\circ} \mathrm{C}$ until reach to constant weight to determine the belowground dry matter production. Above-and belowground relative neighbor effects (ARNE and BRNE) among the mixed species were determined using aboveand belowground dry matter production as in the formula that given by Oksanen et al. (2006).

$$
\mathrm{RNE}=\left(\mathrm{X}_{\mathrm{m}}-\mathrm{X}_{\mathrm{c}}\right) / \operatorname{Max}\left(\mathrm{X}_{\mathrm{m}} \text { or } \mathrm{X}_{\mathrm{c}}\right)
$$

RNE; Relative neighbor effect), $\mathrm{X}_{\mathrm{m}}$; production in mixed sowing, $\mathrm{X}_{\mathrm{c}}$; production in monoculture (control)

All data (year, pea density, and mixture) were controlled by the homogeneity test and subjected to ANOVA in terms of the completely randomized block design with split-plot using SAS 9.3 statistical software (SAS Institute, 2011) and the means were compared using Tukey multiple comparison test.

\section{RESULTS AND DISCUSSION}

Plant heights of pea and cereals were separately measured. It was 145.3 and $104.94 \mathrm{~cm}$ for pea, and 169.7 and $165.47 \mathrm{~cm}$ for cereals in the years of 2018 and 2019 respectively. The height of pea and cereals were varied considering the pea densities in the range of $121.8-127.3$ $\mathrm{cm}$ and $167.1-168.1 \mathrm{~cm}$ respectively. The plant height of pea was measured as $114.8 \mathrm{~cm}$ in control, as $124.9 \mathrm{~cm}$ in $25 \%$ oat, as $115.6 \mathrm{~cm}$ in $50 \%$ oat, as $119.7 \mathrm{~cm}$ in $25 \%$ silage maize, as $140.2 \mathrm{~cm}$ in $50 \%$ silage maize, as 130.4 $\mathrm{cm}$ in $25 \%$ Sudangrass and as $130.5 \mathrm{~cm}$ in $50 \%$ Sudangrass. The height of cereals were $102.9 \mathrm{~cm}$ for oat, $170.3 \mathrm{~cm}$ for silage maize and $229.7 \mathrm{~cm}$ for Sudangrass in the mixtures.

Overall dry matter yield (DMY) was $4334.5 \mathrm{~kg} \mathrm{ha}^{-1}$ and it significantly varied between the years $(\mathrm{P} \leq 0.01)$, among the pea densities ( $\mathrm{P} \leq 0.01)$, mixed sowings ( $\mathrm{P} \leq$ 0.01). Three-way interaction was also significant (Table 2). DMY was higher in the second year of the study (5866.8 $\left.\mathrm{kg} \mathrm{ha}^{-1}\right)$ and the highest value was determined in the 100 plants $\mathrm{m}^{-2}$ density $\left(4722.8 \mathrm{~kg} \mathrm{ha}^{-1}\right)$ while it was the lowest in the density of 120 plants $\mathrm{m}^{-2}\left(3956.1 \mathrm{~kg} \mathrm{ha}^{-1}\right)$ (Table 2). All of the mixed sowings increased the dry matter yield in comparison with the forage pea monoculture, which produced the lowest dry matter (1790.7 $\mathrm{kg} \mathrm{ha}^{-1}$ ), and the highest dry matter yield was determined from $50 \%$ silage maize + forage pea mixtures as $7224.7 \mathrm{~kg} \mathrm{ha}^{-1}$ in overall (Table 2). Silage maize $(50 \%)$ + forage pea (100 plants $\mathrm{m}^{-2}$ ) mixtures produced the highest dry matter yield in both years (Figure 1). Dry matter yield responses of the pea densities varied between years and mixtures (Figure 1), and this caused all interactions to become significant.

Crude protein content was determined as $16.74 \%$ overall. Except for years and pea density, the other main effects and third-order interaction were significant $(\mathrm{P} \leq$ 0.01). The highest crude protein was determined from forage pea monoculture $(19.43 \%)$ and the lowest values were determined in $25-50 \%$ Sudangrass and $50 \%$ oat mixtures $(15.49,14.58$, and $15.95 \%$ respectively) which were ranked in the same group statistically (Table 2). The crude protein content of the pea densities showed various responses when sown in a mixture with the different cereals in each year and this difference caused a significant three-way interaction (Figure 2).

While NDF content significantly changes among the mixtures $(\mathrm{P} \leq 0.01)$, ADF content showed a significant difference between years $(\mathrm{P} \leq 0.01)$ and mixtures $(\mathrm{P} \leq$ 0.01) (Table 2). The differences among the mixtures were slight but statistically significant in terms of NDF and ADF contents (Figure 3, 4). Forage pea monoculture had significantly lower NDF content and Sudangrass mixtures were higher than other mixtures in terms of NDF content but the ADF content significantly varied only between $50 \%$ silage maize and $50 \%$ oat mixtures as 29.89 and $32.68 \%$ respectively (Table 2 ).

The ARNE was facilitative in the first year (0.424) in the pea densities of 100 and 120 plants $\mathrm{m}^{-2}$, in the mixtures with $25-50 \%$ oat and $25 \%$ Sudangrass (Figure 5). It was contrarily competitive in the second year $(-0.252)$, in the pea density of 80 plants $\mathrm{m}^{-2}$, in all maize mixtures, and the mixture with increasing Sudangrass and all interactions were significant (Table 3). The BRNE occurred competitively in all levels of the main effects except the first year, which was facilitative (Table 3) and the second and third-order interactions were significant $(\mathrm{P}$ $\leq 0.01$ and $\mathrm{P} \leq 0.05$ respectively) (Figure 6,7 ). 
Table 2. Analysis of variance results and means of dry matter yield and forage quality

\begin{tabular}{|c|c|c|c|c|}
\hline & Dry matter yield $\left(\mathrm{kg} \mathrm{ha}^{-1}\right)$ & Crude protein $(\%)$ & NDF (\%) & $\mathrm{ADF}(\%)$ \\
\hline \multicolumn{5}{|l|}{ Year (Y) } \\
\hline 2018 & $2802.2 \mathrm{~b}$ & 17.04 & 44.65 & $29.97 \mathrm{~b}$ \\
\hline 2019 & $5866.8 \mathrm{a}$ & 16.45 & 43.53 & $32.32 \mathrm{a}$ \\
\hline \multicolumn{5}{|l|}{ Pea density $(\mathrm{P})$} \\
\hline 80 plant $\mathrm{m}^{-2}$ & $4324.6 \mathrm{~b}$ & 16.54 & 43.75 & 30.99 \\
\hline 100 plant $\mathrm{m}^{-2}$ & $4722.8 \mathrm{a}$ & 17.08 & 44.43 & 30.95 \\
\hline 120 plant $\mathrm{m}^{-2}$ & $3956.1 \mathrm{c}$ & 16.61 & 44.08 & 31.49 \\
\hline \multicolumn{5}{|l|}{ Mixture (M) } \\
\hline Control (Sole-sown) & $1790.7 \mathrm{e}$ & $19.43 \mathrm{a}$ & $41.20 \mathrm{~d}$ & $30.81 \mathrm{bc}$ \\
\hline $25 \%$ Oat & $3330.1 \mathrm{c}$ & $17.67 \mathrm{~b}$ & $43.62 \mathrm{c}$ & $31.11 \mathrm{bc}$ \\
\hline $50 \%$ Oat & $2672.1 \mathrm{~d}$ & $15.95 \mathrm{~cd}$ & $44.21 \mathrm{bc}$ & $32.68 \mathrm{a}$ \\
\hline $25 \%$ Silage maize & $5139.1 \mathrm{~b}$ & $17.20 \mathrm{~b}$ & $43.82 \mathrm{c}$ & $30.66 \mathrm{bc}$ \\
\hline $50 \%$ Silage maize & $7224.7 \mathrm{a}$ & $16.90 \mathrm{bc}$ & $43.65 \mathrm{c}$ & $29.89 \mathrm{c}$ \\
\hline $25 \%$ Sudangrass & $5022.5 \mathrm{~b}$ & $15.49 \mathrm{de}$ & $45.70 \mathrm{ba}$ & $31.19 \mathrm{bc}$ \\
\hline $50 \%$ Sudangrass & $5162.2 \mathrm{~b}$ & $14.58 \mathrm{e}$ & $46.42 \mathrm{a}$ & $31.69 \mathrm{ab}$ \\
\hline Mean & 4334.5 & 16.74 & 44.08 & 31.14 \\
\hline \multicolumn{5}{|c|}{$A N O V A$} \\
\hline $\mathrm{Y}$ & $* *$ & $\mathrm{~ns}$ & $\mathrm{~ns}$ & $* *$ \\
\hline $\mathrm{P}$ & $* *$ & ns & ns & ns \\
\hline M & $* *$ & $* *$ & $* *$ & $* *$ \\
\hline$Y \times P$ & $* *$ & $* *$ & $* *$ & $*$ \\
\hline$Y \times M$ & $*$ & $* *$ & $* *$ & $* *$ \\
\hline $\mathrm{P} \times \mathrm{M}$ & $* *$ & $* *$ & $* *$ & $* *$ \\
\hline $\mathrm{Y} \times \mathrm{P} \times \mathrm{M}$ & $* *$ & $* *$ & $* *$ & $* *$ \\
\hline
\end{tabular}

ns: non-significant, $*: \mathrm{P} \leq 0.05, * *: \mathrm{P} \leq 0.01$

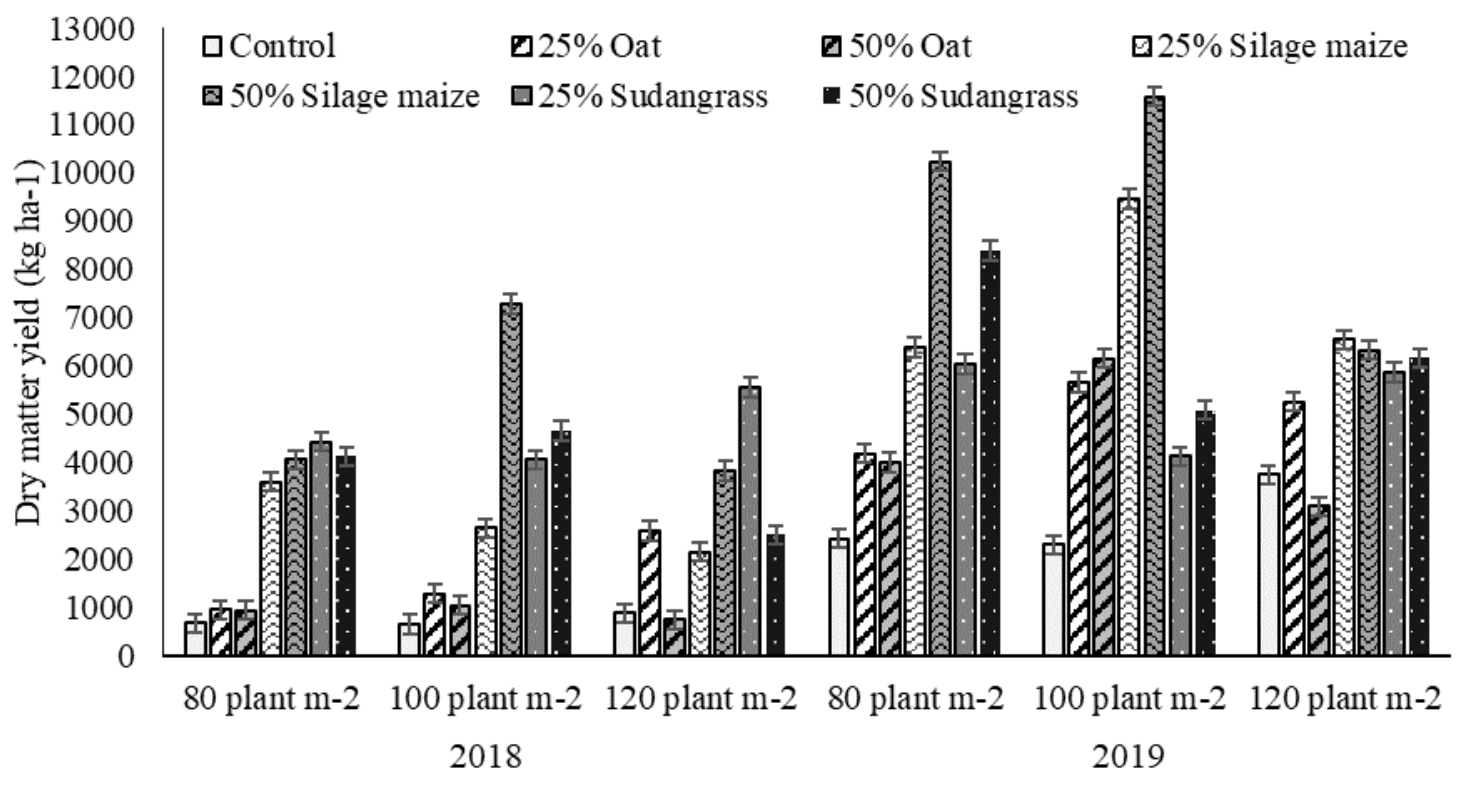

Figure 1. Dry matter yield of the mixtures in different years and forage pea densities 


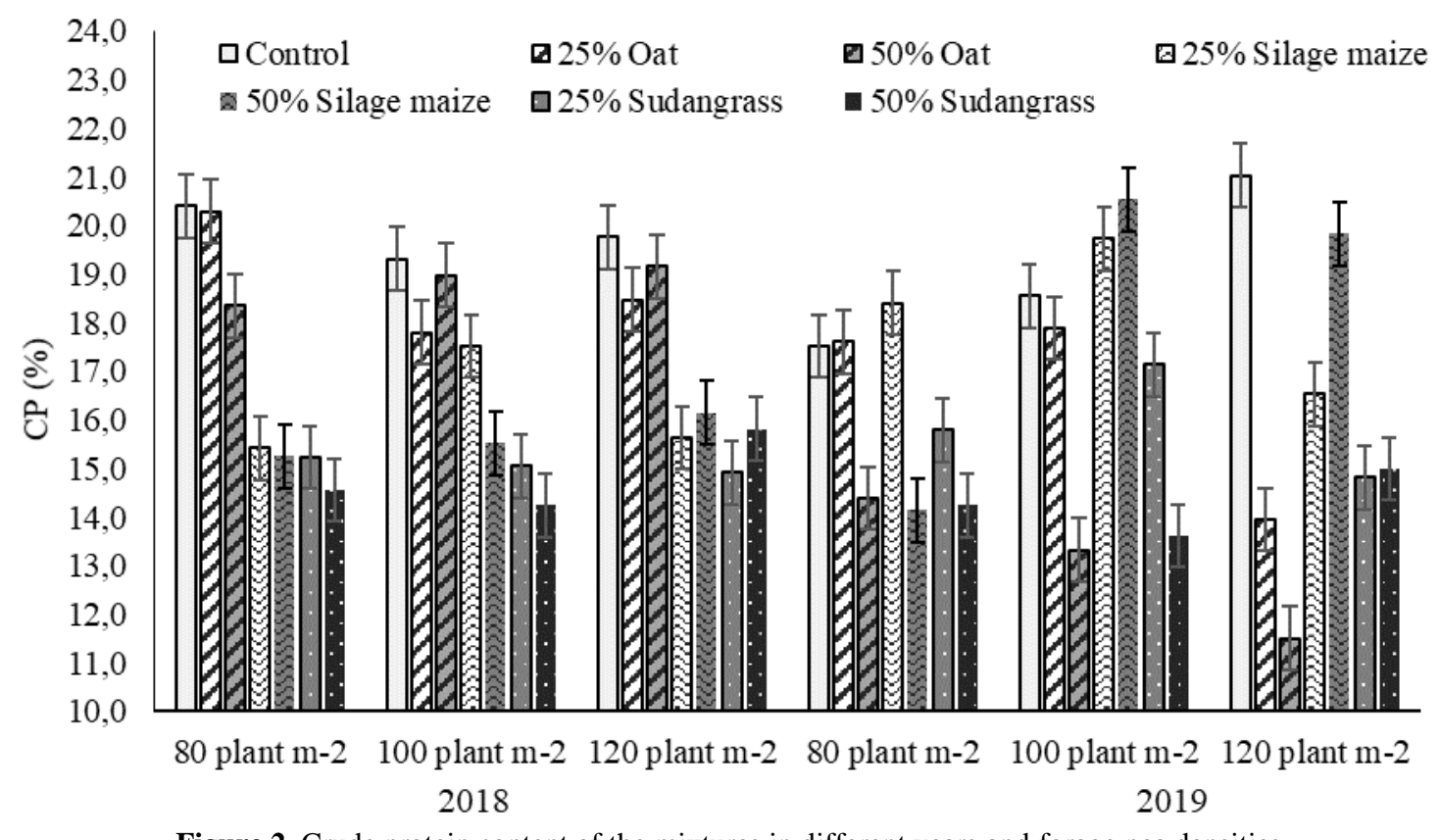

Figure 2. Crude protein content of the mixtures in different years and forage pea densities

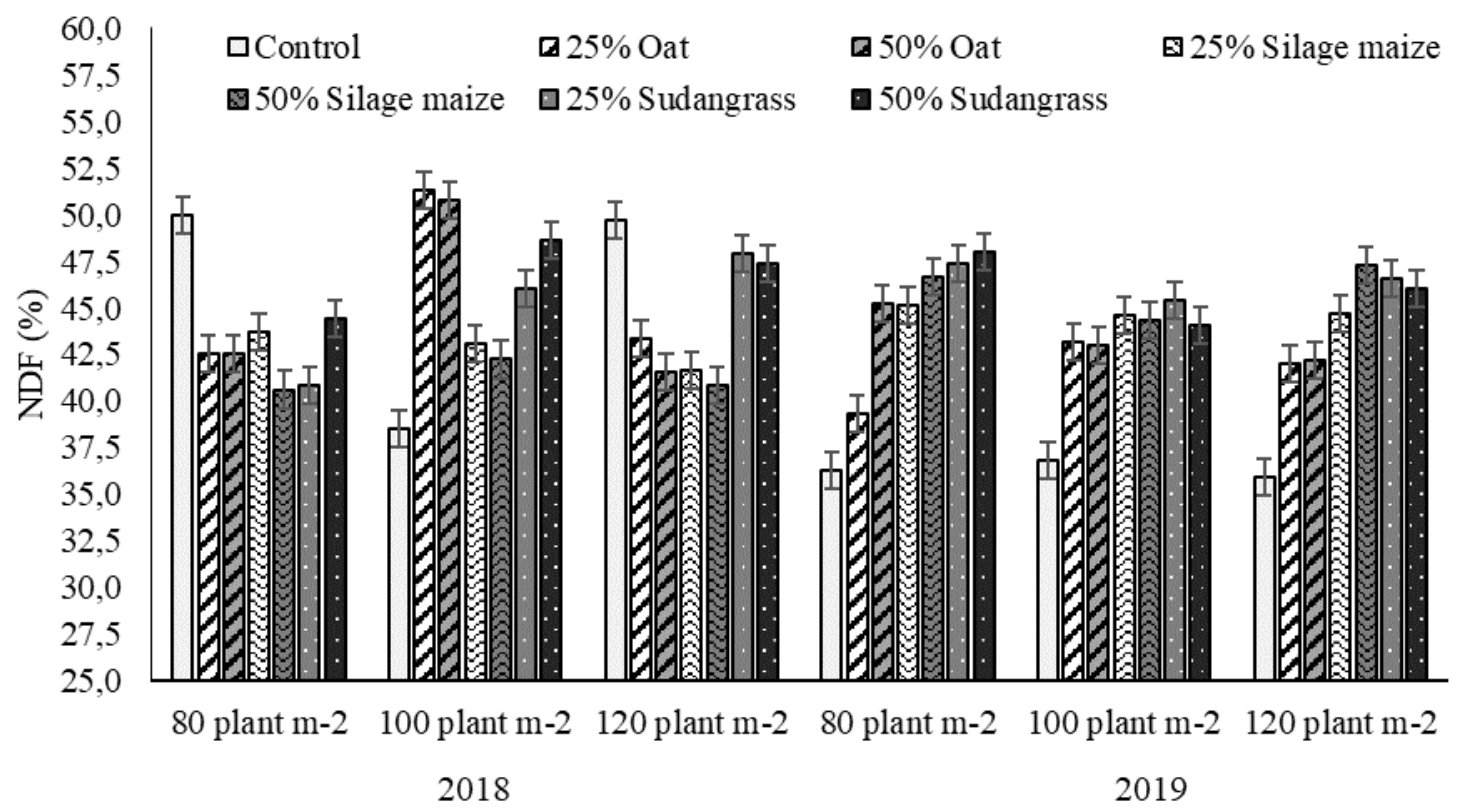

Figure 3. NDF content of the mixtures in different years and forage pea densities 


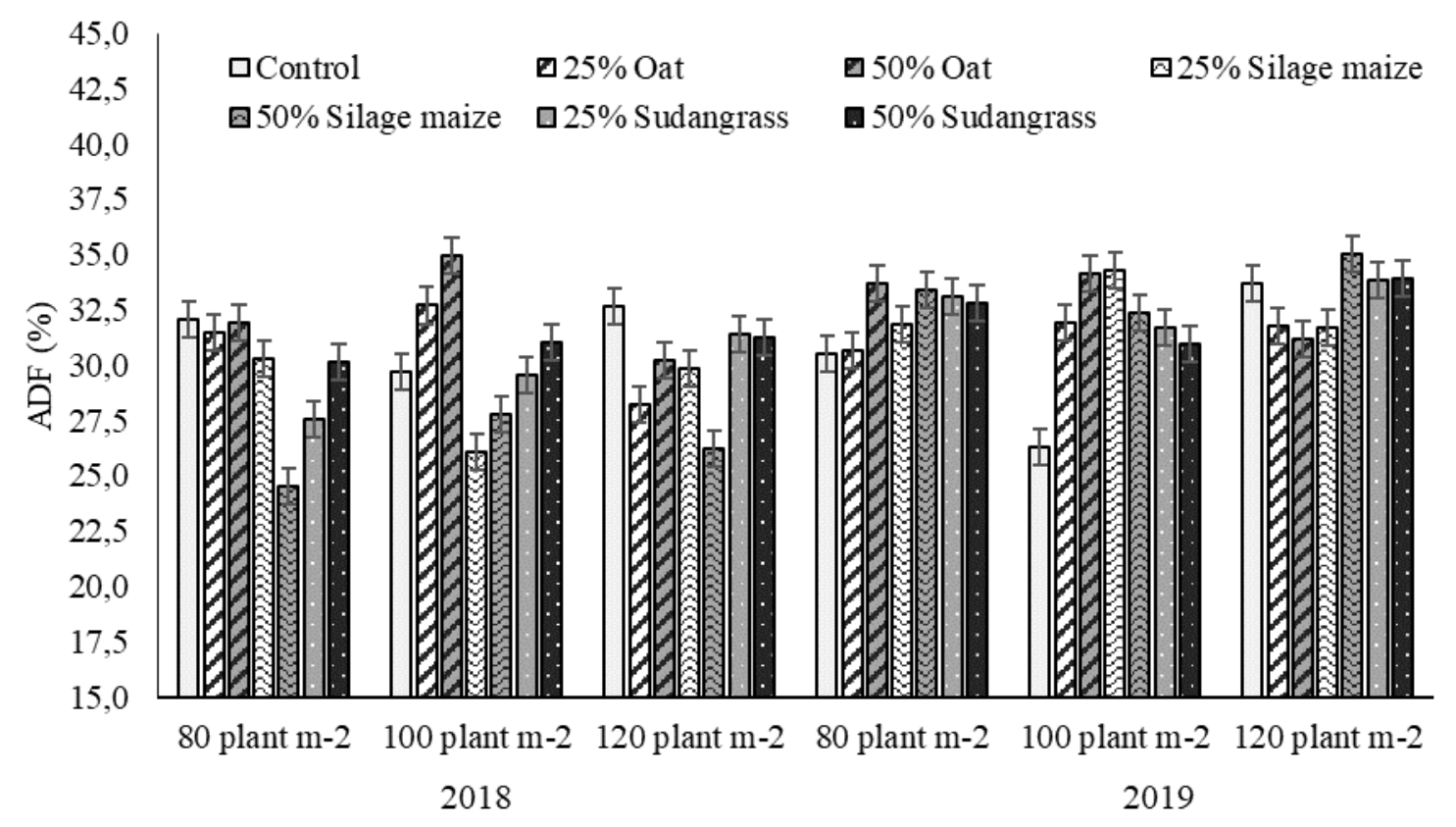

Figure 4. ADF content of the mixtures in different years and forage pea densities

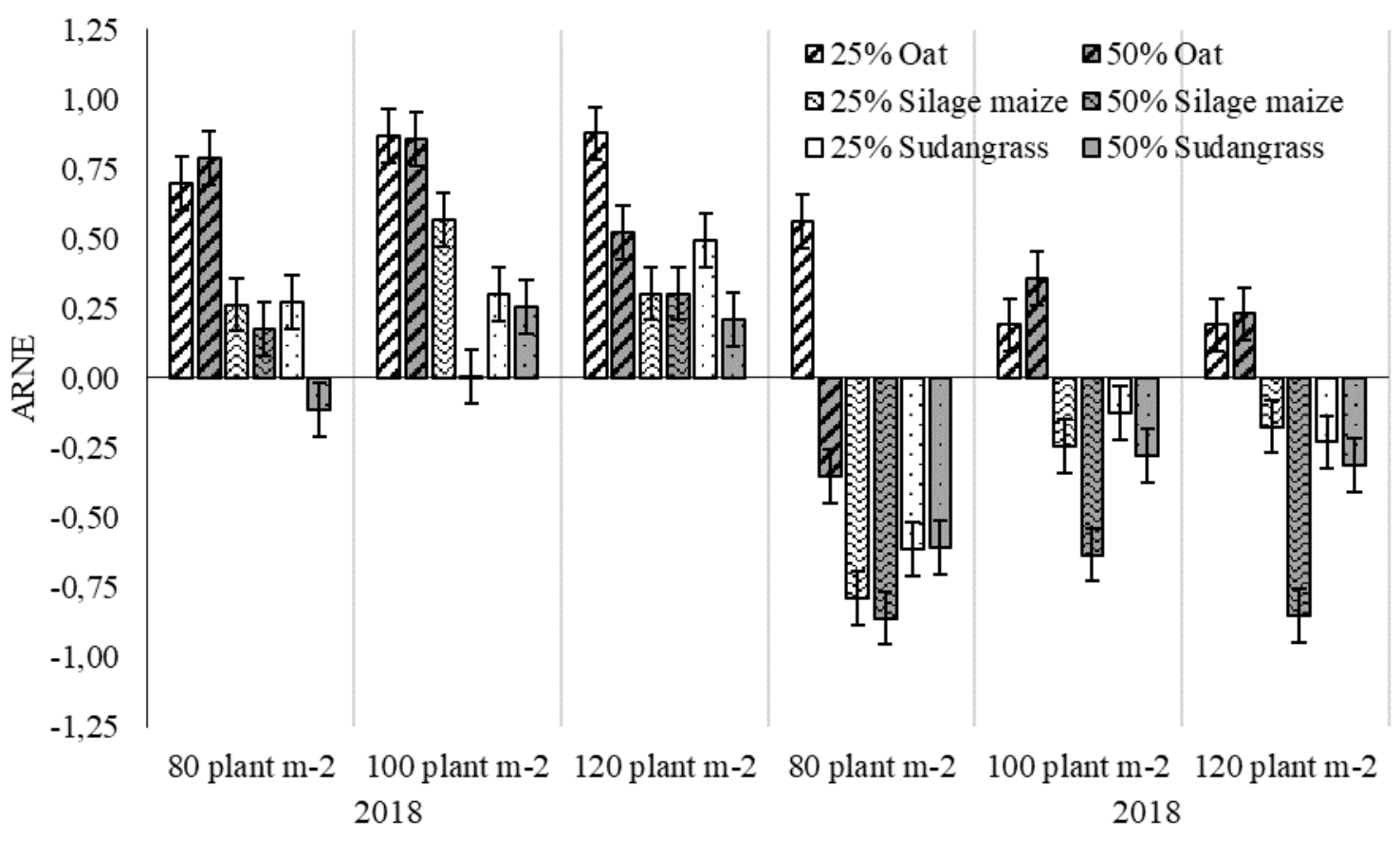

Figure 5. ARNE of the cereals in different years and forage pea densities 
Table 3. ARNE and BRNEs of cereals on forage pea for different years and pea densities

\begin{tabular}{|c|c|c|}
\hline & ARNE & BRNE \\
\hline \multicolumn{3}{|l|}{ Year $(Y)$} \\
\hline 2018 & $0.424 \mathrm{a}$ & $0.159 \mathrm{a}$ \\
\hline 2019 & $-0.252 b$ & $-0.921 b$ \\
\hline \multicolumn{3}{|l|}{ Pea density $(P)$} \\
\hline 80 plant $\mathrm{m}^{-2}$ & $-0.048 b$ & -0.346 \\
\hline 100 plant $\mathrm{m}^{-2}$ & $0.176 \mathrm{a}$ & -0.413 \\
\hline 120 plant $\mathrm{m}^{-2}$ & $0.130 \mathrm{a}$ & -0.382 \\
\hline \multicolumn{3}{|l|}{ Mixture (M) } \\
\hline Control (Sole-sown) & - & - \\
\hline $25 \%$ Oat & $0.563 \mathrm{a}$ & $-0.252 \mathrm{a}$ \\
\hline $50 \%$ Oat & $0.400 \mathrm{~b}$ & $-0.357 \mathrm{ab}$ \\
\hline $25 \%$ Silage maize & $-0.012 c$ & $-0.432 b$ \\
\hline $50 \%$ Silage maize & $-0.310 \mathrm{~d}$ & $-0.355 a b$ \\
\hline $25 \%$ Sudangrass & $0.015 \mathrm{c}$ & $-0.439 b$ \\
\hline $50 \%$ Sudangrass & $-0.140 \mathrm{c}$ & $-0.448 \mathrm{~b}$ \\
\hline Mean & 0.086 & -0.381 \\
\hline \multicolumn{3}{|l|}{$A N O V A$} \\
\hline $\mathrm{Y}$ & $* *$ & $* *$ \\
\hline $\mathrm{P}$ & $* *$ & ns \\
\hline M & $* *$ & $* *$ \\
\hline $\mathrm{Y} \times \mathrm{P}$ & $*$ & ns \\
\hline $\mathrm{Y} \times \mathrm{M}$ & $* *$ & $* *$ \\
\hline $\mathrm{P} \times \mathrm{M}$ & $* *$ & $*$ \\
\hline $\mathrm{Y} \times \mathrm{P} \times \mathrm{M}$ & $* *$ & ns \\
\hline
\end{tabular}

ns: non-significant, $*: \mathrm{P} \leq 0.05, * *: \mathrm{P} \leq 0.01$
The dry matter yield of the plants significantly affected by climatic factors like precipitation, temperature, light, etc. (Uzun et al., 2005; Acikgoz et al., 2013). Our experiment was carried out in irrigated conditions and therefore, especially temperature played a deterministic role on yearly dry matter yield variations and warmer temperatures in 2018 (Table 1) caused a decrease in the dry matter yield possibly due to cool-season characteristics of forage pea. Another effective factor was the pea density and the best result was recorded in 100 plants $\mathrm{m}^{-2}$ density, which was also suggested by researchers (Uzun et al., 2005; Tan et al., 2013). Regardless of the pea density, monoculture and oat mixed forage pea had lower dry matter yield especially in 2018 (Figure 1) when the temperature was higher (Table 1). Surely high-yielded silage maize and Sudangrass caused an increment but the alleviative effect of silage maize and Sudangrass on heat stress of forage pea might be another reason for the higher dry matter yield of the mixtures. This type of effect on mixtures was also reported for peacereals mixtures (Lithourgidis et al., 2011; Kocer and Albayrak, 2012). The dry matter yields of silage maize and Sudangrass mixtures were also lower in 2018. The main reason for this situation might be originated from the negative effect of high temperature on pea growth.
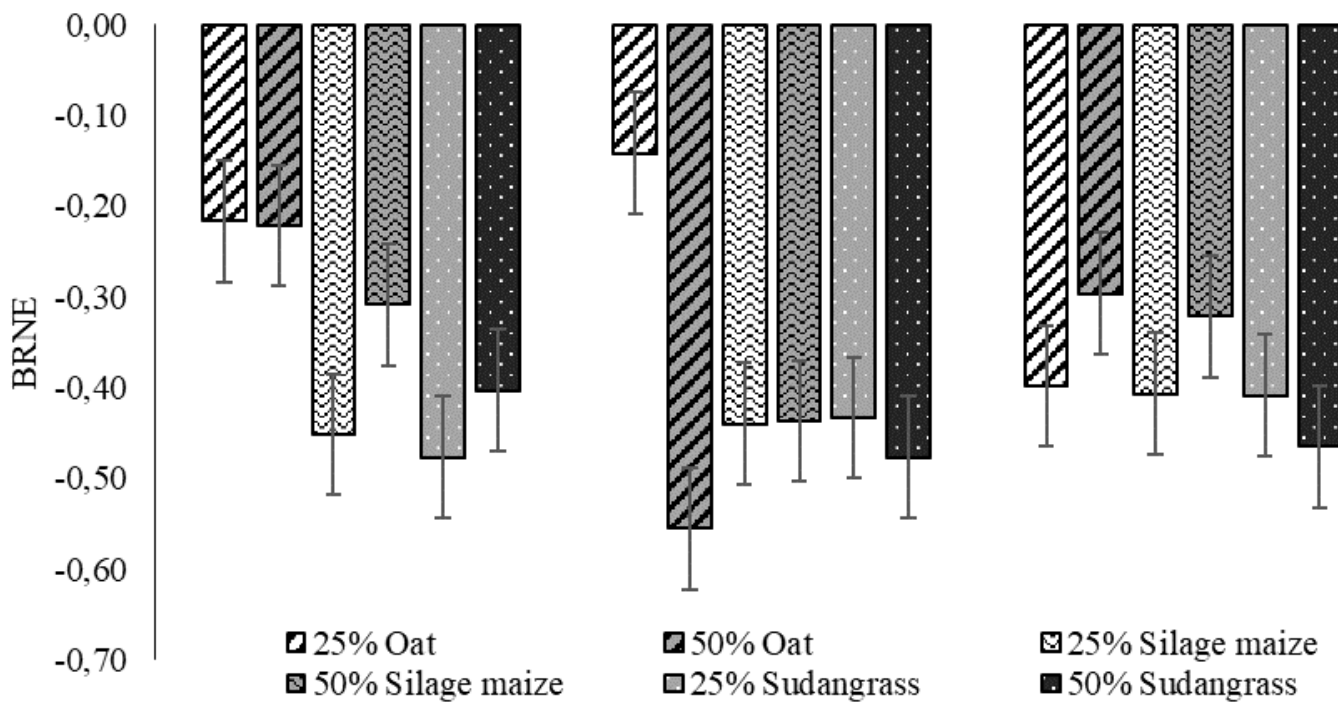

Figure 6. BRNE of the cereals in different forage pea densities

The crude protein content of forage pea monoculture was higher than all mixtures, which was an expected result because it is known that legume species generally have higher crude protein content than cereal species (Arzani et al., 2006; Zhang et al., 2015). Despite the high protein content, sole sowed forage pea do not produce satisfying dry matter (Lithourgidis et al., 2011; Baxevanos et al., 2017) especially in the warm second crop season of dry climate (Table 2). The differences in climatic condition between the years affect growing condition, hence pea densities and mixtures' effect on crude protein content changed depending on these factors (Figure 2). As our findings, some researchers (Mao et al., 2012; Yang et al., 2018) reported that growing performance of the plant grown as sole or in mixture showed different performances depending on the differences between years (Carr et al., 2004; Pflueger et al., 2020). Although there are some differences, mixtures showed partly consistent CP content among years, pea densities, and mixtures. This situation was the main reason for three-way interaction. 


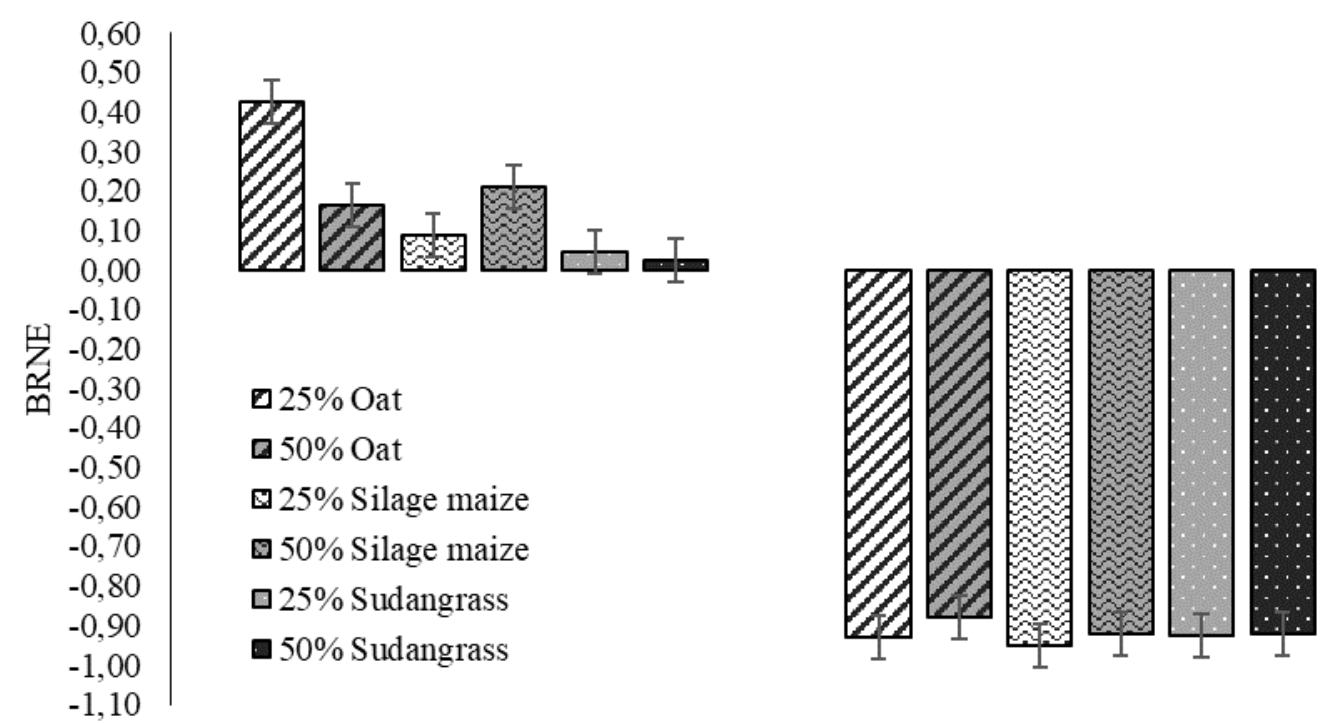

Figure 7. BRNE of the cereals in different years

$\mathrm{NDF}$ and ADF contents affect the dry matter intake of the ruminants (Collins and Fritz, 2003), and plant species (Onal-Asci and Acar, 2018), plant maturity plays a deterministic role in these contents (Kavut and Geren, 2017). Higher ADF content in 2019 is related to a higher cereal ratio in the harvested forage because cereal species have higher NDF and ADF contents than legume species (Lopez et al., 2005; Arzani et al., 2006). Mixtures increased the NDF content of forage pea concerning monoculture because of the higher structural carbohydrate content of the cereals (Collins and Fritz, 2003), and generally, Sudangrass mixtures were observed to have a higher NDF content. Even there were not major ADF differences among the mixtures, it significantly increased up to $32.68 \%$ when the oat ratio was reduced by $50 \%$ in the mixture (Table 2). The differences in climatic conditions affect NDF and ADF contents depending on years, pea densities and mixtures Figure 3, 4). Also our results supported by some researchers (Kocer and Albayrak, 2012; Yavuz, 2017). Genetically and morphologically different plant species may cause significant variation in NDF and ADF contents. As a result of this, third-order interaction was significant.

The relative neighbor effect shifted into competition in the second year of the study (Table 3). Plant-plant interactions may shift between competition and facilitation depending on the stress sources as environmental conditions (Bowker et al., 2010; Grant et al., 2014). Precipitation and temperature means were lower in 2019 (Table 1) but lower temperatures might have been effective in the shift from facilitative interaction to competition because the experiment was conducted in irrigated conditions. We may indicate that high summer temperatures created stressful conditions for forage pea but pea + cereal mixtures indicated facilitative relations due to this stress factor. This idea could be supported by the findings of some researchers that indicating plant-plant interactions could be facilitative under stressful environment conditions (Brooker et al.,
2008; Zhu et al., 2015). Moreover, higher cereal density in 2019 also could be effective in the occurrence of competitive relation because many researchers indicated the high-competitive nature of the cereals (Corre-Hellou et al., 2006; Lithourgidis et al., 2006). Pea density was another factor affecting the ARNE slightly but statistically significant (Table 3). Nearly neutral ARNE, which was nearly neutral in the density of 80 plants $\mathrm{m}^{-2}$ slightly shifted to facilitation with the increasing pea density (Table 3). Therefore, 100 or 120 plants $\mathrm{m}^{-2}$ density could be used in the pea + cereal mixtures. $75 \%$ reduced Sudangrass and silage maize had nearly neutral ARNE on forage pea in the mixture but it increased competitively when the ratio of these cereals increased, especially silage maize (Table 3 ). On the contrary, all oat mixtures had facilitative aboveground relations with the forage pea, which was higher in $75 \%$ reduced oat + forage pea. Researchers (Neumann et al., 2007; Uzun et al., 2012; Baxevanos et al., 2017) also reported many other benefits of oat + forage pea intercrops but BRNE was competitive for all examined cereal species. Jacob et al. (2017) indicated that pea was negatively affected by the belowground presence of any other species and this result supports our findings.

\section{CONCLUSION}

Forage pea and cereal (oat, silage maize, Sudangrass) mixtures produced satisfying dry matter with good quality but climate plays a deterministic role on yield. Even the cereals, not oat, affect the aboveground production of forage pea negatively under favorable conditions, the forage quality was still in high-quality standards in terms of crude protein content, NDF, and ADF contents. Results indicated that forage pea with a density of 100 plants $\mathrm{m}^{-2}$ could be sown in a mixture of $50 \%$ reduced silage maize (50000 plants $\mathrm{ha}^{-1}$ ) under second crop conditions of the Central Anatolia Region because of its high yield and quality. Growing performance of the plant grown as sole or in mixture showed different performances depending on the differences between years, pea densities and 
mixtures. This research indicates that the plant-plant interactions could have a significant effect on the forage yield and performance of the mixtures especially in the second crop conditions of semi-arid regions.

\section{LITERATURE CITED}

Acikgoz, E. 2001. Forage Crops. VIPAS Publication Number 58. Bursa (In Turkish).

Acikgoz, E., M. Sincik, G. Wietgrefe, M. Surmen, S. Cecen, T. Yavuz, C. Erdurmus and A.T. Goksoy. 2013. Dry matter accumulation and forage quality characteristics of different soybean genotypes. Turkish Journal of Agriculture and Forestry 37(1): 22-32.

Arzani, H., M. Basiri, F. Khatibi and G. Ghorbani. 2006. Nutritive value of some Zagros Mountain rangeland species. Small Ruminant Research 65(1-2): 128-135.

Basaran, U., E. Gulumser, H. Mut and M. Copur Dogrusoz. 2018. Determination of silage yield and quality of grasspea+cereal intercrops. Turkish Journal of Agriculture Food Science and Technology 6(9): 1237-1242.

Baxevanos, D., I.T. Tsialtas, D.N. Vlachostergios, I. Hadjigeorgiou, C. Dordas and A. Lithourgidis. 2017. Cultivar competitiveness in pea-oat intercrops under Mediterranean conditions. Field Crops Research 214: 94103.

Bhattacharya, A. 2019. Changing Climate and Resource Use Efficiency in Plants. Academic Press, London, UK.

Bowker, M.A., S. Soliveres and F.T. Maestre. 2010. Competition increases with abiotic stress and regulates the diversity of biological soil crusts. Journal of Ecology 98(3): 551-560.

Brooker, R.W., F.T. Maestre, R.M. Callaway, C.L. Lortie, L.A. Cavieres, G. Kunstler, P. Liancourt, K. Tielborger, J.M.J. Travis, F. Anthelme, C. Armas, L. Coll, E. Corcket, S. Delzon, E. Forey, Z. Kikvidze, J. Olofsson, F. Pugnaire, C.L. Quiroz, P. Saccone, K. Schiffers, M. Seifan, B. Touzard and R. Michalet. 2008. Facilitation in plant communities: the past, the present, and the future. Journal of Ecology 96: 1834.

Carr, P.M., R.D. Horsley and W.W. Poland. 2004. Barley, oat, and cereal-pea mixtures as dryland forages in the northern Great Plains. Agronomy Journal 96(3): 677-684.

Collins, M. and J.O. Fritz. 2003. Forage quality. In: Forages: An Introduction to Grassland Agriculture (6th ed.), ed. Barnes, R.F., Nelson, C.J., Collins, M. and Moore, K.J., 363-390, Iowa State Press, Ames.

Cook, D., A.M. Rimando, T.E. Clemente, J. Schroder, F.E. Dayan, N.P.D. Nanayakkara, Z. Pan, B.P. Noonan, M. Fishbein, I. Abe, S.O. Duke and S.R. Baerson. 2010. Alkylresorcinol synthases ecpressed in Sorghum bicolor root hairs play an essential role in the biosynthesis of the allelopathic benzoquinone sorgoleone. The Plant Cell 22(3): 867-887.

Corre-Hellou, G., J. Fustec and Y. Crozat. 2006. Interspecific competition for soil $\mathrm{N}$ and its interaction with $\mathrm{N} 2$ fixation, leaf expansion and crop growth in pea-barley intercrops. Plant and Soil 282(1-2): 195-208.

Grant, K., J. Kreyling, H. Heilmeier, C. Beierkuhnlein and A. Jentsch. 2014. Extreme weather events and plant-plant interactions: shifts between competition and facilitation among grassland species in the face of drought and heavy rainfall. Ecological Research 29(5): 991-1001.

He, Q., M.D. Bertness and A.H. Altieri. 2013. Global shifts towards positive species interactions with increasing environmental stress. Ecology Letters 16: 695-706.
Jacob, C.E., E. Tozzi and C.J. Willenborg. 2017. Neighbour presence, not identity, influences root and shoot allocation in pea. PLoS One 12(3): e0173758.

Jiang, Y., R. Lahlali, C. Karunakaran, S. Kumar, A.R. Davis and R.A. Bueckert. 2015. Seed set, pollen morphology and pollen surface composition response to heat stress in field pea. Plant, Cell \& Environment 38(11): 2387-2397.

Kavut, Y.T. and H. Geren. 2017. Effects of different harvest dates and mixture rates on the yield and some silage quality characteristics of legume mixtures with annual ryegrass (Lolium multiflorum L.). Journal of Agriculture Faculty of Ege University 54(2): 115-124 (In Turkish).

Koc, A., S. Erkovan H.I. Erkovan, U. Oz, M.M. Birben and R. Tunc. 2013. Competitive effects of plant species under different sowing ratios in some annual cereal and legume mixtures. Journal of Animal and Veterinary Advances 12: 509-520

Kocer, A. and S. Albayrak. 2012. Determination of forage yield and quality of pea (Pisum sativum L.) mixtures with oat and barley. Turkish Journal of Field Crops 17(1): 96-99.

Kontturi, M., A. Laine, M. Niskanen, T. Hurme, M. Hyovela and P. Peltonen-Sainio. 2011. Pea-oat intercrops to sustain lodging resistance and yield formation in northern European conditions. Acta Agriculturae Scandinavica, Section B-Soil and Plant Science 61(7): 612-621.

Lithourgidis, A.S., I.B. Vasilakoglou, K.V. Dhima, C.A. Dordas and M.D. Yiakoulaki. 2006. Forage yield and quality of common vetch mixtures with oat and triticale in two seeding ratios. Field Crops Research 99(2-3): 106-113.

Lithourgidis, A.S., D.N. Vlachostergios, C.A. Dordas and C.A. Damalas. 2011. Dry matter yield, nitrogen content, and competition in pea-cereal intercropping systems. European Journal of Agronomy 34(4): 287-294.

Liu, N., C. Karunakaran, R. Lahlali, T. Warkentin and R.A. Bueckert. 2019. Genotypic and heat stress effects on leaf cuticles of field pea using ATR-FTIR spectroscopy. Planta 249(2): 601-613.

Lopez, S., D.R. Davies, F.J. Giraldez, M.S. Dhanoa, J. Dijkstra and J. France. 2005. Assessment of nutritive value of cereal and legume straws based on chemical composition and in vitro digestibility. Journal of the Science of Food and Agriculture 85(9): 1550-1557.

Mao, L., L. Zhang, W. Li, W. van der Werf, J. Sun, H. Spiertz and L. Li. 2012. Yield advantage and water saving in maize/pea intercrop. Field Crops Research 138: 11-20.

Mihailovic, V., A. Mikic and B. Cupina. 2007. Potential of annual legumes for utilization in animal feeding. Biotechnology in Animal Husbandry 23: 573-581.

Moreira, F.B., I.N. Prado, U. Cecato, F.Y. Wada and I.Y. Mizubuti. 2004. Forage evaluation, chemical composition, and in vitro digestibility of continuously grazed star grass. Animal Feed Science and Technology 113(1-4): 239-249.

Neumann, A., K. Schmidtke and R. Rauber. 2007. Effects of crop density and tillage system on grain yield and $\mathrm{N}$ uptake from soil and atmosphere of sole and intercropped pea and oat. Field Crops Research 100(2-3): 285-293.

Oksanen, L., M. Sammul and M. Merike. 2006. On the indices of plant-plant competition and their pitfalls. Oikos 112: 149155.

Onal-Asci, O., Z. Acar and Y.K. Arici. 2015. Hay yield, quality traits and interspecies competition of forage pea - triticale mixtures harvested at different stages. Turkish Journal of Field Crops 20(2): 166-173.

Onal-Asci, O. and Z. Acar. 2018. Quality in Roughage. TMMOB Chamber of Agricultural Engineers, Ankara (In Turkish). 
Pflueger, N.P., D.D. Redfearn, J.D. Volesky and R. Bolze, M.B. Stephenson. 2020. Influence of oat and spring pea mixtures on forage characteristics in different environments. Agronomy Journal 112(3): 1911-1920.

Planton, S., P. Lionello, V. Artale, R. Aznar, A. Carillo, J. Colin, L. Congedi, C. Dubois, A. Elizalde, S. Gualdi, E. Hertig, J. Jacobeit, G. Jorda, L. Li, A. Mariotti, C. Piani, P. Ruti, E. Sanchez-Gomez, G. Sannino, F. Sevault, S. Somot and M. Tsimplis. 2012. The climate of the Mediterranean region in future climate projections. In: Mediterranean Climate Variability, ed. Lionello P., 449-502, Amsterdam, Netherlands, Elsevier.

Podgorska-Lesiak, M. and P. Sobkowicz. 2013. Prevention of pea lodging by intercropping barley with peas at different nitrogen fertilization levels. Field Crops Research 149: 95104.

Rogelj, J., M. Meinshausen and R. Knutti. 2012. Global warming under old and new scenarios using IPCC climate sensitivity range estimates. Nature Climate Change 2(4): 248-253.

SAS Institute Inc. 2011. Base SAS 9.3 Procedures Guide, NC.

Smitchger, J. and N. Weeden. 2019. Quantitative trait loci controlling lodging resistance and other important agronomic traits in dry field peas. Crop Science 59(4): 1442-1456.

Tan, M., A. Koc, Z. Dumlu Gul, E. Elkoca and I. Gul. 2013. Determination of dry matter yield and yield components of local forage pea (Pisum sativum ssp. arvense L.) ecotypes. Journal of Agricultural Sciences 19: 289-296.

Tafesse, E.G., T.D. Warkentin and R.A. Bueckert. 2019. Canopy architecture and leaf type as traits of heat resistance in pea. Field Crops Research 241: 107561.

Turgut, I., A. Duman, U. Bilgili and E. Acikgoz. 2005. Alternate row spacing and plant density effects on forage and dry matter yield of corn hybrids (Zea mays L.). Journal of Agronomy and Crop Science 191(2): 146-151.

Uzun, A., U. Bilgili, M. Sincik, I. Filya and E. Acikgoz. 2005. Yield and quality of forage type pea lines of contrasting leaf types. European Journal of Agronomy 22(1): 85-94.

Uzun, A. and F.F. Asik. 2012. The effect of mixture rates and cutting stages on some yield and quality characters of pea (Pisum sativum L.)+oat (Avena sativa L.) mixture. Turkish Journal of Field Crops 17(1): 62-66.

Van Soest, P.J., J.B Robertson and B.A. Lewis. 1991. Methods for dietary fiber, neutral detergent fiber, and non-starch polysaccharides in relation to animal nutrition. Journal of Dairy Science 74: 3583-3597.

Weigelt, A. and P. Jolliffe. 2003. Indices of plant competition. Journal of Ecology 91(5): 707-720.

Yang, C., Z. Fan and Q. Chai. 2018. Agronomic and economic benefits of pea/maize intercropping systems in relation to $\mathrm{N}$ fertilizer and maize density. Agronomy 8(4): 52.

Yavuz, T. 2017. The effects of different cutting stages on forage yield and quality in pea (Pisum sativum L.) and oat (Avena sativa L.) mixtures. Journal of Central Research Institute for Field Crops 26(1): 67-74 (In Turkish).

Zhai, L.C., R.Z. Xie, B. Ming and S.K. Li. 2018. Evaluation and analysis of intraspecific competition in maize: A case study on plant density experiment. Journal of Integrative Agriculture 17(10): 2235-2244.

Zhang, J., B. Yin, Y. Xie, J. Li, Z. Yang and G. Zhang. 2015. Legume-cereal intercropping improves forage yield, quality and degradability. PLoS One 10(12): e0144813.

Zhu, J., L. Jiang, Y. Zhang, Y. Jiang, J. Tao, L. Tian, T. Zhang and Y. Xi. 2015. Below ground competition drives the self thinning process of Stipa purpurea populations in northern Tibet. Journal of Vegetation Science 26(1): 166-174. 